\title{
A Literature Review, Container Shipping Supply Chain: Planning Problems and Research Opportunities
}

\author{
Dongping Song (iD
}

check for updates

Citation: Song, D. A Literature Review, Container Shipping Supply Chain: Planning Problems and Research Opportunities. Logistics 2021, 5, 41. https://doi.org/10.3390/ logistics5020041

Academic Editors:

Kristina Čižiūnienè,

Ieva Meidutè-Kavaliauskienè, Darja Topolšek and Adam Torok

Received: 31 May 2021

Accepted: 17 June 2021

Published: 21 June 2021

Publisher's Note: MDPI stays neutral with regard to jurisdictional claims in published maps and institutional affiliations.

Copyright: (C) 2021 by the author. Licensee MDPI, Basel, Switzerland. This article is an open access article distributed under the terms and conditions of the Creative Commons Attribution (CC BY) license (https:/ / creativecommons.org/licenses/by/ $4.0 /)$.
School of Management, University of Liverpool, Chatham Street, Liverpool L69 7ZH, UK;

Dongping.Song@liverpool.ac.uk

\begin{abstract}
This paper provides an overview of the container shipping supply chain (CSSC) by taking a logistics perspective, covering all major value-adding segments in CSSC including freight logistics, container logistics, vessel logistics, port/terminal logistics, and inland transport logistics. The main planning problems and research opportunities in each logistics segment are reviewed and discussed to promote further research. Moreover, the two most important challenges in CSSC, digitalization and decarbonization, are explained and discussed in detail. We raise awareness of the extreme fragmentation of CSSC that causes inefficient operations. A pathway to digitalize container shipping is proposed that requires the applications of digital technologies in various business processes across five logistics segments, and change in behaviors and relationships of stakeholders in the supply chain. We recognize that shipping decarbonization is likely to take diverse pathways with different fuel/energy systems for ships and ports. This gives rise to more research and application opportunities in the highly uncertain and complex CSSC environment.
\end{abstract}

Keywords: container shipping supply chain; transport logistics; literature review; digitalization; decarbonization

\section{Introduction to CSSC}

Container transport is regarded as the world's truly global supply chain due to the fact that a single cargo-laden container can be moved by different transport vehicles (e.g., vessels, trains, and trucks) and handled by various types of handling equipment and facilities (e.g., terminals, cranes, trailers, wagons, lifters, and depots) from origin to destination along the entire end-to-end supply chain. The importance of the container shipping sector is supported by the facts that over $70 \%$ of world trade by value is carried by the seaborne transport mode, and over $50 \%$ of world seaborne trade by value is carried by container ships according to the 2018 annual review of maritime transport by The United Nations Conference on Trade and Development. The container shipping supply chain (CSSC) consists of several key stakeholders such as the shipper, freight forwarder, shipping line, port/terminal operator, inland carrier, and intermodal terminal/depot operator.

According to the main business operations of these stakeholders, the CSSC may be classified into five value-adding segments [1,2]: Shipment arrangement; Container management; Seaborne transport; Port and terminal management; Inland transport \& depot management. From the logistics management perspective, the five value-adding segments may be interpreted as: freight logistics, container logistics, vessel logistics, port/terminal logistics, and inland transport logistics. Specifically, freight logistics focuses on the arrangement of the storage, routing and scheduling of cargos and containerized shipments. Container logistics focuses on the planning and control of the container fleet to meet customer requirements and better utilize the container fleet. Vessel logistics focuses on the planning and control of the containership fleet to provide reliable shipping services to shippers by maximizing profit or minimizing the logistics costs. Port and terminal logistics focuses on the provision of efficient services to vessels, trains and external trucks when handling and storing containers at port. Inland transport logistics focuses on the planning 
and control of inland vehicle fleets (mainly trucks and trains) and facilities (depots, railheads and intermodal terminals) to transport, store and maintain containers in the inland region [3].

There has been a plethora of studies in each of the above logistics segments in CSSC. Although a number of survey papers have reviewed the literature in one or several segments of CSSC, few studies cover the main planning issues across the entire CSSC in a coherent way. This paper attempts to provide a more complete view of the main operations management problems in end-to-end CSSC, raise awareness of the fragmentation of CSSC, and point out the research opportunities in CSSC. Moreover, we discuss the two most important challenges that CSSC is facing recently, i.e., digitalization and decarbonization, and explain the pathways towards CSSC digitalization and decarbonization.

The rest of the paper is organized as follows. In Sections 2-6, we explain the main planning problems in the five logistics segments in CSSC including freight logistics, container logistics, vessel logistics, port/terminal logistics, and inland transport logistics, respectively. The further research opportunities in each individual segment are discussed. In Section 7, the two most important challenges that CSSC is facing recently, digitalization and decarbonization, are explained and discussed. We stress the phenomenon of extreme fragmentation in CSSC. The pathways toward CSSC digitalization and decarbonization are elaborated. Conclusions are drawn in the final section.

\section{Freight Logistics}

In the CSSC context, freight logistics concerns the efficient and effective flow and storage of containerized cargo from exporter's warehouse to importer's warehouse by using the most appropriate transport mode for each segment of the journey in the end-toend CSSC. Clearly, it is appropriate to take the shipper's or freight forwarders' viewpoint when managing freight logistics since they are the cargo owners. The common planning activities and processes in freight logistics include:

- $\quad$ selecting transport modes and carriers;

- $\quad$ negotiating delivery terms and freight rates;

- $\quad$ contracting with ocean carriers;

- $\quad$ arranging relevant documents and customs clearance;

- consolidation and decomposition;

- $\quad$ arranging inland pickup and delivery;

- container shipment routing and scheduling;

- container storage and transshipping.

Among these planning activities, the most important physical activities are probably consolidation, transportation, transshipping, and decomposition, which covers the supply chain from the warehouse or depot in the export country through domestic inland transport, port of origin, seaborne transport, port of destination, foreign inland transport, to the warehouse or depot in the import country.

As the end-to-end CSSC usually involves both seaborne transport and inland transport, the CSSC tends to use multiple transport modes. This gives rise to the phenomenon of intermodal or multimodal transport, which tries to take advantage of the inherent economic benefits or the unique characteristics of each transport mode. For example, the maritime transport mode has the advantage of low cost over long inter-continental distance, whereas the road transport mode has the advantage of high accessibility for the "first mile" or "last mile" delivery. Specifically, intermodal transport can be defined as the movement of goods in a single loading unit through two or more successive modes of transport without handling the goods themselves in changing the mode of transportation [4]. This concept is particularly suitable for CSSC.

An interesting development of intermodal transport is synchro-modal transport, which adds the feature of real-time switching among various available transport modes during the journey in a flexible manner. Several studies have explored the feasibility and advantages of synchro-modal transport in container shipping. For example, Agbo et al. [5] 
addressed the feasibility of synchro-modal freight transportation and pointed out three key notions:

- the extended gate, which links the seaport to the inland intermodal terminal using high-capacity transport such as barge and rail;

- the pull-to-push strategy, in which containers are directly transported by barges or trains from seaports to inland terminals to avoid containers waiting at seaports for collection by individual customers;

- the mode-free booking, which enables shippers to sign a container transportation contract with specified price, time of container delivery, level of service quality, but without specified transport modes in the delivery journey.

The critical success factors (CSFs) for synchro-modal transport are discussed in [6-8]. In particular, Giusti et al. [8] summarized the following CSFs of synchro-modality: collaboration and trust among stakeholders to better integrate their networks and coordinate operations, sophisticated and dynamic planning to make full use of available resources and real-time data, information communication technologies (ICT) and an intelligent transport system (ITS) to gather data and share information, physical infrastructure and a network with smart hubs, awareness and a mental shift from traditional booking to mode-free booking, and appropriate service pricing mechanism. Among the above CSFs, ICT/ITS is regarded as a meta-CSF that enables others. They identified six groups of enabling technologies: traceability, intelligent systems, data analytics, optimization, simulation, and integrated platforms [8]. However, the application of synchro-modal transport in practice is still rather limited.

The most common planning issue in freight logistics is probably the container shipment assignment and routing in the intermodal transport network. At the global scale, there are many CSSCs and they interact because they share common resources such as ports, vessels, handling equipment, human resources and facilities. Therefore, shipment assignment and routing exist at three planning levels: individual level, multiple level and industry-wide level. The individual level focuses on the routing of a specific shipment within a shipping network, which may be solved by the shortest path method. The multiple level focuses on the assignment of a set of shipments over the shipping network; and the industry-wide level considers the different identities and behaviors of the shipments and the different behaviors and attitudes of the stakeholders in CSSCs across the container industry. The last two planning levels are more challenging because of capacity constraints and the interactions of shipments and stakeholders.

From the modelling perspective, the shipment assignment and routing problems can be addressed by a top-down approach or bottom-up approach. The top-down approach often applies mathematical programming methods to optimize the shipment assignment and routing in a given transport network, where the organizational identities of shippers and shipping lines are often ignored. For example, Liu et al. [9] took the shipping lines' perspective to model a global intermodal shipping network with the emphasis on shipping network design. Shibasaki et al. [10] took the cargo owners' perspective to assign container flows over a global intermodal network including both seaborne transport and inland transport. Their focus is on predicting how the shipment flow will change in response to the change of transport service levels. Halim et al. [11] proposed an integrated model for the global freight transportation system using a multi-level framework, which laid a foundation for developing a discrete-event simulation. Huang et al. [12] considered the assignment of world containerized trade over the global maritime container network. Two modelling methods were applied. The first method is based on the traditional travel demand modelling technique which is a sequential process including trip generation and distribution. The second method is a joint model methodology. They compared the results of these two methods and evaluated the impact of infrastructure such as ports, coastline length and being an island on the containerized trade volume. Note that the top-down methods treat the transportation system as an integrated system under the 
control of a single company. Therefore, the results may be regarded as the ideal solution to the routing and assignments of trade demands over the global shipping network.

The bottom-up approach tries to capture the individual entities' behaviors and decision-making activities, which often applies the agent-based modelling method or multi-agent system. This is more natural and closer to the realistic global shipping system because individual shipping companies are independent and competing in practice. In the literature, agent-based modelling (ABM), complex adaptive systems (CAS), and multi-agent systems (AMS) have been used in the container transport sector. Such agent technologies are more suitable to model the container shipping supply chains because many heterogenous and autonomous agents (stakeholders) are involved in CSSC. Even for the same type of agent, e.g., shipping lines, there are a large number of independent companies which coexist and compete in the global container transport business. These companies adopt different operational strategies and behave differently in terms of service network provision, ship fleet deployment, container fleet management, and freight pricing and contracting. Such heterogeneity and complex interactions, including both competition and cooperation between the involved entities, make the bottom-up agent-based modelling approaches more appropriate. A few studies have applied ABM, CAS and MAS in the context of global container shipping (e.g., $[13,14])$. One of the main challenges of successfully applying the bottom-up methods is the difficulty in collecting the relevant data and the rules for individual entities associated with the global shipping networks and inland transport networks. Nevertheless, at a relatively narrow scope, e.g., container port and terminal operations, there have been more applications of ABM and MAS, e.g., [15-18]. With the development of information communication technologies and artificial intelligence, it is believed that ABM, CAS and MAS may attract more attention for modelling freight logistics in the context of CSSCs [3].

The focal companies of freight logistics in CSSC are shippers and freight forwarders. The interesting research opportunities in this logistics segment include:

(i) Haulage contracting between shippers and shipping lines. Under merchant haulage, the shipper is responsible for the inland movement of the container. Under carrier haulage, the shipping line is responsible for both the movements of the container at sea and in inland. Shippers need to assess and compare different haulage contracts.

(ii) Terms of sale (delivery terms) agreement between exporter and importer. The delivery terms specify the responsibility of relevant stakeholders for arranging the movement of the container and the location where the ownership of the goods within the container is transferred from the exporter to the importer. Shippers need to evaluate different incoterms issued by the International Chamber of Commerce, considering the total logistics cost and the associated risk.

(iii) Carrier and service selection. Apart from the freight rate, shippers need to consider other indirect costs, e.g., the cycle-stock cost caused by the transit time, the safetystock cost caused by the unreliability of the service schedule, and the financial risk that may be caused by the bankruptcy of relevant stakeholders (e.g., the bankruptcy of Hanjin Shipping in 2016 caused many containers to be stranded at ports or on vessels at sea).

(iv) Contracting with carriers. Shippers and freight forwarders are facing historically high freight rates for long-term contracted containers in 2021. Even when the long-term contracts are signed, they still have to face the possibility that shipping lines may break agreements and rollover cargos in order to take advantage of more lucrative spot rates. In this regard, a game theory may be used to balance long-term contract with spot contract under uncertainty.

(v) The implementation of synchro-modal transport in practice. This requires collaboration and commitment among the stakeholders across multiple CSSCs.

(vi) The development of ABM, CAS and MAS models for CSSCs. This can be helped by making use of innovative technologies, big data and machine learning, e.g., utilizing the real-time data from AIS (Automatic Identification System), which is a vessel 
tracking system fitted to all commercial vessels and transmits vessel-related data via radio signals.

\section{Container Logistics}

Container logistics concerns the efficient and effective management of container flows and storage in transport networks to meet customer demands and maximize the utilization of the container fleet. According to Drewry Shipping Consultant, the world container fleet exceeded 37 million twenty-equivalent units (TEUs) in 2018, which were owned mainly by shipping lines and container lessors roughly at a 50:50 split. The container fleet is the most important asset to shipping companies, second only to the container vessels in terms of capital investment. As an equipment asset, containers have two states in the logistics processes, i.e., laden container (with cargo inside container) and empty container (without cargo inside container). Laden containers are often regarded as shipments with their routing largely specified by shippers or freight forwarders, while empty containers are moving equipment for reuse, whose storage and flows are largely determined by shipping companies. In order to improve the utilization of the container fleet, it is vital for shipping companies to manage the empty container logistics efficiently. Broadly, container logistics includes the following planning problems:

- Container fleet sizing;

- Container leasing and off-leasing;

- $\quad$ Laden container canvassing, routing and dispatching;

- $\quad$ Empty container repositioning (ECR).

Container fleet sizing concerns the number and types of container in the fleet that will be used and reused in a transport system. A larger fleet size may decrease the need for empty container repositioning but will incur higher capital and inventory costs. Container fleet sizing is also highly related to the leasing decisions and container manufacturing costs. In addition, a shipping company's operational strategy may also affect the fleet sizing decision. For example, when a shipping company adopts the slow steaming practice, it will require a larger container fleet because more containers are tied up on vessels at sea. Container leasing is a contractual relationship between a container lessor and a shipping company regarding a temporary lease of a set of containers. Container leasing is an important activity in CSSC because shipping companies heavily rely on leased containers to complement their owned container fleets in order to reduce the capital investment. Trip-based spot leasing can reduce the need for empty container repositioning. However, there is a trend that container leasing agreements tend to be long-term agreements lasting for several years. Laden container canvassing, routing and dispatching refers to the management of container shipments in the transport networks. It is largely in the scope of freight logistics. However, if the shipping service is a carrier haulage (door-to-door service), then the shipping line will be responsible for arranging the movements of the laden containers from origin to destination in the most efficient way. Shipment canvassing at surplus areas can reduce the need for ECR. Moreover, because both laden containers and empty containers share the capacitated resources in the same transport networks (e.g., vessels, trains and trucks), container logistics should coordinate laden container canvassing, routing and dispatching together with ECR. Empty container repositioning refers to managing the flows and storage of empty containers in transport networks, which is the primary planning task of container logistics. ECR is fundamentally driven by the imbalance of laden container movements. Clearly, the management of laden containers, e.g., by pricing the freight rate appropriately, may mitigate the degree of trade imbalance.

From the logistics channel perspective, the solution measures to the ECR problems may be classified into four categories: organizational measures, intra-channel measures, inter-channel measures, and technological measures [19]. From the modelling perspective, the existing solution models may be classified into two broad research streams: network flow models, and inventory-control models. Braekers et al. [20] reviewed the ECR models with the emphasis on regional empty container logistics. They categorized the ECR 
models into three planning levels, i.e., strategic, tactical, and operational levels. Song and Dong [19] reviewed the literature on ECR problems emphasizing global empty container logistics including both network flow models and inventory-control models. Kuzmicz and Pesch [21] reviewed the literature on empty container modelling problems considering technical solutions and optimization methods.

In the research stream of network flow models, a variety of models have been presented for global shipping networks or intermodal transport networks, e.g., network optimization model within a decision support system [22], container flow-balancing models [23], stochastic programming models [24,25], time-space network flow models (e.g., [26-28]), scenario-based linear programming or mixed-integer programming models [29,30], mixed-integer linear programming model considering purchasing [31], stochastic linear programming model [32], flow-balancing models considering foldable containers [33,34], multicommodity capacitated network flow problem considering perishable products [35], and multi-commodity network flow problem considering combinable containers [36]. In general, network flow models often produce a matrix of empty container flows between nodes (in static situations), or a time-stamped matrix of empty container flows between nodes (in time-dependent situations). The main advantage of the network flow models is that they can provide a guideline plan and offer a big picture of empty container flows in the transport network.

In the research stream of inventory-control models, the application context is often subject to sequential decision making and uncertain demand over time. The focus is to execute dynamic control of the inventory of empty containers in response to updated information. The stochastic dynamic programming method is often used to derive the explicit forms of the optimal ECR policies in various settings, for example, in one-port or one-depot systems (e.g., [37-40]); in two-port or two-depot systems (e.g., [41-44]); or in multiple-port systems (e.g., $[39,45])$. Inventory-control ECR policies can lead to simple parameterized threshold-type control policies, which are easy to understand and easy to implement with minor requirements of real-time data and information communication. For example, Kanban-type and base-stock-type ECR policies are proposed for cyclic shipping service routes with uncertain demands [3,46]; the (s, S)-type ECR policies are optimized using meta-heuristics in shipping service routes [47-49]; a single-threshold ECR policy is optimized in a multi-port system using the infinitesimal perturbation analysis method [50]; the (s, S)-type policies for regional inland transport systems are optimized using genetic algorithms [51,52]. The main advantage of the inventory-control ECR policies is that they are rule-based policies, which are robust and flexible to manage empty containers on a real-time basis with quick response to dynamic and uncertain information.

In general, network flow models are good at centralized planning for deterministic systems, and inventory-control models are good at decentralized control for stochastic dynamic systems. As the CSSC has a global coverage including both long-distance intercontinental repositioning of empty containers and short-distance regional repositioning of empty containers, it is reasonable to adopt a hierarchical framework to tackle the ECR problems in the end-to-end CSSC by combining the network flow model and the inventorycontrol model. One way to combine these two types of model is to use the network flow model to design tactic plans for ECR at aggregated and long-term planning level, and use inventory-control rules to determine ECR at an operational and real-time control level when implementing the tactic ECR plans. Alternatively, one may pre-specify a parameterized inventory-control policy for individual depots (such as safety stock levels), and then use network flow models to determine the ECR at an operational level. In this regard, Epstein et al. [53] presented a two-stage model for ECR in a complex global shipping network with multiple service routes. The first stage is an inventory model to determine the inventory levels at each depot in the transport network considering uncertain supply and demand of empty containers. The second stage is a multi-commodity multi-period network flow model to determine daily empty container repositioning in the shipping network. However, their model did not explicitly consider laden container movements. 
Xing et al. [54] proposed a simulation-based two-stage optimization model for a global tank container operator's dynamic operation planning including ECR, subject to multiple types of uncertainties. The first stage addresses tactical decisions of optimizing threshold parameters within the inventory-control ECR policies. The second stage addresses operational decisions including job acceptance and rejection, container leasing, and empty container flows. Their two-stage model is solved by utilizing a set of methods such as Genetic Algorithm, mathematical programming, and heuristic rules.

The focal companies of container logistics are shipping lines and container lessors as these are the container owners. Although container logistics, especially ECR, has been extensively studied in the last two decades, many topics deserve further research, e.g.,

(i) Container logistics covers a range of planning activities such as fleet sizing, leasing and off-leasing, laden container canvassing, routing and dispatching, and empty container repositioning. It is desirable to integrate these activities together in the context of CSSC so that their interactions could be better represented. This requires the collaboration of multiple functions within the shipping company and multiple stakeholders along the CSSC.

(ii) Empty container repositioning can be seriously affected by shipping lines' strategy and port/terminals' policies. For example, the breakout of COVID-19 and the demand drop in the first half of 2020 caused shipping lines to adopt blank sailing strategy, which left many empty containers in European and North American ports. When trade demand suddenly picked up in the second half of 2020, most Asian ports experienced a severe shortage of empty containers. Moreover, some container ports may adopt a policy of refusing empty containers entering the port due to yard congestion, which further complicates the empty container repositioning.

(iii) When the laden containers reach customers, it is common that customers may overhold the containers (i.e., keep the containers longer than the agreed time). This phenomenon is called detention. Detention incurs cost to shippers and prevents shipping lines from managing the container fleet efficiently. How to set up free detention time and how to price the detention charge for overholding have a significant impact on container logistics. Moreover, containers may be damaged during the transportation processes, which leads to logistics issues such as where and when to perform maintenance, repair and cleaning. Containers differ in size, type and grade, and shippers have different preferences for container types. Hence, container logistics management could be extended to consider these operational details practically.

(iv) Empty container movements not only incur costs, but also cause environmental and social impacts, e.g., emissions, pollutions, congestions, and accidents. The traditional externality of the environmental and social impacts may be internalized within the container logistics models. This leads to sustainable performance of container logistics including economic, environmental and social aspects. Different players have different perceptions of sustainable performances and may also have different risk attitude towards uncertainty.

(v) From the logistics channel perspective, container logistics problems could be addressed from several categories of solution measures such as organizational measures, intra-channel measures, inter-channel measures, and technological measures. It is believed that there is a need to combine different measures (e.g., mitigating the root causes, seeking efficient organizational strategies, collaborating with channel members, collaborating with competitors, and adopting innovative technologies) to tackle the challenges in container logistics effectively [55].

\section{Vessel Logistics}

Vessel logistics concerns the management of shipping service supply and relevant information flows to meet shippers' transport demands efficiently and effectively. The vessel fleet is the most capital-intensive asset for a shipping company in providing container 
transport services. The main planning problems associated with vessel logistics in CSSC can be classified into strategic, tactical and operational planning levels in Table 1 [3].

Table 1. Planning problems associated with vessel logistics in CSSC.

\begin{tabular}{cc}
\hline Planning Level & Planning Activities \\
\hline Strategic level planning & $\begin{array}{c}\text { Trade lane and market coverage selection and expansion; } \\
\text { Horizontal integration \& strategic alliance; Shipping line } \\
\text { competition; Vertical integration; Long-term contracting } \\
\text { strategy; Ship design; Fuel and energy system selection; Ship } \\
\text { fleet size and mix; Ship chartering }\end{array}$ \\
& $\begin{array}{c}\text { Shipping network design and redesign; Fleet deployment \& } \\
\text { redeployment; Ship routing and adjustment; Ship scheduling } \\
\text { and timetabling; Ship speed \& service frequency planning; } \\
\text { Ship laying-up; Ship recycling; Inventory routing; Shipment } \\
\text { routing; Container fleet management }\end{array}$ \\
\hline Oplanning level & $\begin{array}{c}\text { Spot-market pricing; Empty container repositioning; Ship } \\
\text { speed optimization; Slow steaming; Ship rescheduling; Ship } \\
\text { repositioning; Environmental/weather routing; Disruption } \\
\text { event management; Container stowage planning; Ship } \\
\text { bunkering; Ship loading/unloading }\end{array}$ \\
\hline
\end{tabular}

There have been voluminous studies addressing the various planning problems associated with vessel logistics. At the strategic planning level, commonly studied topics include horizontal cooperation and competition among shipping lines (e.g., [56-58]); and the vertical integration between shipping lines and other stakeholders along the CSSC (e.g., [59-62]). From the modelling perspective, these planning problems are often based on aggregated data or joined together with tactical and operational planning tasks in order to evaluate the effects of the strategic decisions.

At the tactical planning level, there have been a few comprehensive review papers that focused on one or several specific planning issues, e.g., [63-68]. The commonly studied tactical planning problems in CSSC include network design $[65,67,69]$, ship routing, ship scheduling and fleet deployment $[64,66,70]$, and ship schedule design [71,72]. Two unique features that make container shipping differ from other shipping sectors are the regularity of the shipping services and the transshipment across multiple service routes. These features make the service network design, fleet deployment and schedule design challenging, especially in the presence of uncertainty. It is therefore common that these tactical planning problems are tackled separately or in a multi-stage structure. By decoupling these planning issues, the overall planning problem becomes more tractable mathematically and computationally.

At the operational planning level, there are a number of short-term or real-time activities in CSSC. The common planning activities include ECR (e.g., [19]), ship speed optimization (e.g., [73-75]), slow steaming (e.g., [76-79]), container stowage planning (e.g., [80]), disruption management (e.g., [81-84]), and ship bunkering [85,86]. However, there is no clear cut distinction between operational decisions and tactical decisions. In fact, many operational decisions are dealt with at the tactical level by treating the decisions as static variables, e.g., the planned ship sailing speed.

The focal company for vessel logistics is the shipping line (or ocean carrier). Shipping is a rather conservative and risk-averse industry, partially due to the nature of capital intensiveness and the high level of uncertainty. The regularity of container shipping services implies that the vessels are required to stick to the published timetable regardless of whether the vessels are under-utilized. The global coverage of the CSSC implies the involvement of a large number of different players that makes the relationships between these players complicated and varying over time. Although fruitful research results have been obtained in this logistics segment, some areas deserve more attentions, e.g., 
(i) The majority of existing optimization models for vessel logistics either consider deterministic situations or implicitly assume risk-neutral performance measures. The conservative behavior and risk-averse attitude of the channel members in CSSC have been under-studied.

(ii) Shipping lines have been relentlessly pursuing larger vessels to achieve economy of scale and cut operational costs, which has led to severe over-capacity and fierce competition. Some shipping lines are gradually turning to profitability strategies rather than merely cost-cutting strategies, e.g., capacity management, revenue management, diversification and differentiation. As a result, more research could be done in relation to shipping lines' profitability strategies.

(iii) The bankruptcy of Hanjin Shipping in 2016 caused chaos in CSSC because container cargos were left stranded around the world which disrupted shippers' production and inventory worldwide. Shippers and freight forwarders became increasingly concerned over counterparty risk. As a result, shipping lines should pay more attention to ship financing and cashflow to gain competitive advantages.

(iv) Many events can change the trade volume and demand patterns, e.g., the US-China trade war shifted a significant amount of US trade from China to other Asian countries; the COVID-19 pandemic triggered changes in consumption and shopping patterns resulting in a surge of containerized trade in the second half of 2020 (due to increased demand for manufactured consumer goods). Shipping lines need to manage the shipping service supply appropriately in anticipation or response to the change in trade patterns.

(v) Severe disruption at ports can occur. Shipping lines have to design contingency plans for service disruption and service recovery. For example, the Port of Yantian stopped entry of export containers from 25 to 27 May 2021 for four days because of an ongoing coronavirus outbreak in the port area. The local authority ordered 14-day quarantine period for vessels with infected crew on board. Not only the owner of the infected vessel, but also other shipping lines were impacted. Up to 11 June 2021, in total 153 container vessels have been impacted and 132 have completely omitted the South China region. The ripple effects have already been felt across supply chains [87].

(vi) Ship crew management became a serious issue due to COVID-19. The safety, security and welfare of crew members deserved more attention. The crew exchange became much more complicated because some ports were not allowed to exchange ship crew, and some ports did not have flights to send the crew back home. This is a new challenge that the shipping industry has to face. There is a rich literature on crew scheduling in the aviation sector. However, the research methods and results may not easily be adapted to the shipping sector.

(vii) The Suez Canal was blocked by the 20,388 TEU containership Ever Given on 23 March 2021. When the Canal was finally re-opened on 29 March 2021, more than 350 ships were already queuing at both ends and many ships diverted to the Cape of Good Hope to circumvent the Suez Canal. Its impacts have rippled to ports and shippers globally that caused port congestion and shipment delays. This accident prompted the need for research on the better planning for ships accessing capacity-constrained infrastructures, better and reliable operations on board ship, scenario analysis for major accidence, and disruption management in CSSC.

\section{Port and Terminal Logistics}

Ports are gateways for cargo and passenger transported by seagoing ships. A port may consist of several terminals, which specialize in handling certain types of commodity. Container ports and container terminals are often used interchangeably, designed as an interface to transfer containers between ships and other transport modes. From the import perspective, containers arrive at a container terminal at a large volume that are unloaded from a ship and then are transported to hinterland shippers via different transport modes (e.g., trucks, trains, barges) at a small volume. The container terminal is also equipped 
with various facilities for the maintenance and storage of containers. Therefore, port and terminal logistics can be defined as the efficient and effective service provision to associated stakeholders such as shipping lines, road hauliers, rail operators, freight forwarders and shippers.

Clearly, the main goal of port/terminal logistics is to improve the efficiency and productivity of port operations. A large number of studies have been conducted on container port/terminal productivity. A few survey papers, e.g., [88-91], have reviewed the literature on the application of operations research modelling in port logistics processes including ship planning process, storage and stacking logistics, quayside transport, and landside transport. The main planning problems associated with container port/terminal logistics may be categorized into a two-dimensional matrix according to the planning horizon and the logistics process in Table 2 [3]. Some planning issues cut across multiple logistics processes or even the entire port area.

Table 2. Planning problems associated with container port/terminal logistics.

\begin{tabular}{|c|c|c|c|c|}
\hline & Quayside & Yardside & Landside & Across Processes \\
\hline Strategic & $\begin{array}{c}\text { Berth layout } \\
\text { Quay crane selection }\end{array}$ & $\begin{array}{c}\text { Yard layout } \\
\text { Yard equipment }\end{array}$ & $\begin{array}{l}\text { Gate layout } \\
\text { Rail terminal layout }\end{array}$ & $\begin{array}{c}\text { Port competition, Port } \\
\text { cooperation, } \\
\text { Integration, } \\
\text { Multi-modal interfaces, } \\
\text { Terminal layout, IT } \\
\text { systems }\end{array}$ \\
\hline Tactical & $\begin{array}{l}\text { Berth allocation } \\
\text { Quay crane assignment }\end{array}$ & $\begin{array}{c}\text { Storage planning } \\
\text { Resource assignment }\end{array}$ & $\begin{array}{l}\text { Vehicle booking system } \\
\text { Rail service planning }\end{array}$ & \\
\hline Operational & $\begin{array}{l}\text { Quay crane scheduling } \\
\text { Loading/unloading } \\
\text { Workforce scheduling } \\
\text { Internal truck scheduling }\end{array}$ & $\begin{array}{l}\text { Yard crane scheduling } \\
\text { Container relocation } \\
\text { Workforce scheduling } \\
\text { Internal truck scheduling }\end{array}$ & $\begin{array}{l}\text { External truck handling } \\
\text { Wagon shunting } \\
\text { Workforce scheduling } \\
\text { Equipment scheduling }\end{array}$ & \\
\hline
\end{tabular}

Quayside operation is probably the most extensively studied logistics process in container terminals because it is often regarded as the bottleneck in most container terminals around the world (cf. $[90,92,93]$ ). Most of the studies consider the planning issues at different planning levels (such as berth allocation, quay crane assignment, quay crane scheduling) separately or sequentially. Recent studies emphasize the integration of strategic, tactical and operational planning activities at container terminals, e.g., [94,95].

Yard-side operations may be divided into three sub-fields: yard cranes management, yard vehicles management, and yard space management [96]. Yard space management further includes storage space allocation, container stacking, pre-marshalling, re-marshalling and retrieving [97]. Most of these planning activities are closely related to container relocation (also called reshuffling or rehandling). Container relocation is unproductive. It will not only incur a cost to terminal operators but also a waiting time for external trucks or trains. In addition, there is also a need to integrate yard-side operations with quayside operations and/or landside operations (e.g., [98,99]).

Landside operations are divided into the gate operation system interfacing with road hauliers and the rail terminal operations interfacing with rail operators. Vehicle booking systems have been widely applied in container ports to manage the external truck arrivals at the gate systems to avoid gate congestion and reduce truck turnaround time (e.g., [100]). With regard to rail terminal operations, Ambrosino and Siri [101] considered the train load planning problem; Xie and Song [102] optimized the container pre-staging, discharging and loading at a seaport rail terminal. However, the logistics problems at rail terminals are generally under-studied, which is partially due to the fact that rail container traffic is fairly low in many container ports in the world.

The planning issues cutting across different port logistics processes are often at the strategic planning level and have a long-term effect. Port competition and co-opetition is 
one of the most commonly studied issues, e.g., port cooperation [103,104]; port competition and competitiveness [105]; interactions between port competition and the landside transport accessibility [106]. It is argued that cooperation between ports is more sustainable than direct competition [107].

Methodologically, the commonly applied methods in port/terminal logistics include analytical methods (such as mathematical programming; game theory), heuristics or metaheuristic methods, simulation methods, and multi-agent approaches.

The focal organizations of port and terminal logistics are terminal operators and port authorities. The port is a critical node in the global CSSC, where many stakeholders are directly related. The following research opportunities deserve more attention:

(i) Port disruption management. Disruptive events like COVID-19, industrial action, flooding, strong winds, and hurricanes can seriously disrupt port operations and the CSSC. Pro-active and reactive strategies should be planned to improve port and supply chain resilience.

(ii) Port congestion is an industry-wide problem. In the second half of 2020, many European ports (e.g., Felixstowe and Southampton) and North American west-coastal ports (e.g., Los Angeles and Long Beach) reached historically high-level of congestion with no space to put the containers that needed to be discharged from vessels. These ports were congested with empty containers to be repositioned back to Asia and with import laden containers to be moved into hinterland customers. The port congestion problem should be tackled not only by improving efficiency and productivity at ports, but also by joint effort from terminal operators, shipping lines, and inland carriers.

(iii) There are a wide range of planning issues in port logistics. On the one hand, it is desirable to integrate the planning issues across different planning levels (from strategic to operational); on the other hand, it is desirable to integrate the planning issues across different logistics processes (across quayside, yard-side and landside).

(iv) From an academic perspective, many optimization problems in port/terminal logistics have been proved to be NP-hard problems, e.g., berth allocation and crane scheduling, container storage and relocations. Reformulating the planning problems or designing solution algorithms in an innovative way may produce exact optimal solutions.

(v) From a practical perspective, more efficient heuristic algorithms and effective rules that are readily applicable in practice should be developed. According to the feedback from industry experts, a solution for real time decisions should take no more than a second at quayside and no more than a minute at container yards. Hence, there is a balance to strike between optimality and speed when seeking solutions.

(vi) Port logistics should pay more attention to environmental and social performance. The port is a pollution and emission concentration area. Congestion, pollution and emission should be factored into the decision-making process. For example, shifting road container traffic to rails and barges would significantly reduce carbon emission and road congestion.

(vii) A better port community system, which requires the trust, commitment and collaboration among participated stakeholders. Through information sharing and coordinated management, a more efficient port logistics process can be achieved, especially at quayside and landside, which more directly interact with other players. In this regard, digitalization could provide innovative solutions.

\section{Inland Transport Logistics}

Inland transport logistics concerns the management of inland vehicle and depot logistics. It focuses on the planning and control of inland vehicle fleets (mainly trucks and trains) and facilities (depots and equipment) to transport and store containers in the inland region. Inland transport vehicle includes trucks, trains and barges. Trains and barges often run with fixed regular routes and schedules, whereas trucks are flexible in terms of route and time. Inland depots represent intermodal terminals, dry ports and empty 
depots, which provide logistics services such as handling inland vehicles, container storage, maintenance, consolidation, and unpacking.

Hinterland container transport has received much attention due to its indispensable role in both the export and import sides of the global CSSC, and the increasing concerns about road congestion, emission and pollution, and traffic safety. Both laden and empty containers are moving, stored and maintained in the hinterland transport network consisting of ports, depots, and customer warehouses using various transport vehicle and handling equipment. The main planning problems associated with inland transport logistics in CSSC can be summarized in Table 3.

Table 3. Planning problems associated with inland transport logistics in CSSC.

\begin{tabular}{ll}
\hline Logistics Sectors & \multicolumn{1}{c}{ Planning Activities } \\
\hline \multirow{3}{*}{ Truck operations } & Truck fleet management; Truck pooling and sharing; \\
& Container drayage; Vehicle booking system; Empty \\
& vehicle repositioning; Empty container repositioning; \\
& Truck routing and scheduling; Disruptive event \\
& management. \\
\hline & Rail/barge route design; Service timetable design; \\
& Wagon shunting; Barge vessel stowage planning; \\
& Rail-car fleet management; Empty rail-car repositioning; \\
& Container loading and unloading; Transport mode \\
& choice; Carrier selection. \\
\hline & Depot/dry port location; Inland container transport \\
& network design; Depot layout; Container storage; \\
& Container repair and maintenance; Container \\
& substitution; Demurrage and detention; Loading and \\
& unloading; Consolidation and unpacking. \\
\hline
\end{tabular}

Notteboom and Rodrigue [108] presented the concept of regionalization of seaports, which aims to strengthen the connections between seaports and the hinterland by trains and barges. The service regularity and bulk transport capability of trains and barges imply that regionalization essentially expands seaport capacity and therefore relieves congestion at and near seaports. The locations and numbers of inland container depots are often designed in relation to the container routing from the logistics network perspective [109]. Lam and $\mathrm{Gu}$ [110] reviewed the optimization models for port hinterland container transport, which includes both sea-land intermodal transport and land-based intermodal transport. Methodologically, linear programming, integer programming, mixed integer programming, non-linear models, and simulation models have been commonly employed in the literature to tackle inland container transportation problems. Bouchery et al. [111] reviewed the literature on hinterland container transportation systems. At the network design level, they emphasized the importance of coordinating container movements across the container SCs. At the operational level, they identified the important factors that influence the trade-off between intermodal transportation and truck-only transport.

The container drayage problem is similar to the traditional vehicle routing problem. However, containers are classified into different types according to the import/export direction and laden/empty state [112]. In addition, containers can be carried not only by truck but also by train and there may be time windows for containers and timetables for train services. The consideration of demurrage and detention may further complicate the inland container transport problem [113].

The focal companies for inland container transport are inland carriers and depot operators. A number of topics deserve further research in this logistics segment:

(i) Since containers have import/export movement directions and their states take either laden or empty states, inland container transport should incorporate the evolution 
of container types and states. This requires the model to be dynamic and be able to anticipate uncertainties not only in demand but also in lead time.

(ii) Inland container transport is only part of the global CSSC. Therefore, it would be desirable to coordinate or integrate the inland container transport problem into the global CSSC context. Transparency and information sharing across the CSSC is the key enabler for more efficient hinterland intermodal transportation. The concept of synchro-modality and agent-based technologies could be applied in this research direction.

(iii) Note that containers are carried by moving vehicles. After a delivery of containers, it is possible that the vehicle will have an empty run. This leads to an empty vehicle (or rail-car) redistribution problem, which is under the management of inland carriers. There is a lack of research to connect empty container repositioning to empty vehicle redistribution.

(iv) With the increasing green concerns, inland container transport management should evaluate energy consumption and $\mathrm{CO}_{2}$ emission by taking the well-to-wheel and life cycle assessment perspective [114]. In this regard, multiple objective optimization models from the systemwide perspective are needed

(v) Horizontal integration among inland carriers is an interesting topic. By exchanging or pooling vehicles, empty vehicle runs could be reduced so that a win-win situation could be achieved. How to design an appropriate contracting mechanism between these potentially competing inland carriers requires further study. Perhaps, the concept of co-opetition between shipping lines could be applied to the inland transport carriers to achieve horizontal integration.

(vi) Government and local council are likely to issue more stringent environmental regulations such as carbon tax or subsidize the use of greener vehicle. This may influence the vehicle fleet, infrastructure expansion, container flows, and pricing strategies in the inland transport network. Multi-period game models combined with stochastic dynamic programming may be applied in such situations.

\section{Challenges in CSSC: Digitalization and Decarbonization}

Digitalization and decarbonization are among the greatest challenges that the shipping industry will face in the next few years. Shipping is characterized by heterogeneity, fragmentation, uncertainty and complexity. The heterogeneity is reflected by many different types of vessel and different sizes of vessel in each type. Fragmentation is caused by the involvement of a large number of players in the shipping service, the conservative and risk-averse behaviors of the players, and the lack of information sharing and coordination among the players in the supply chains [3]. Uncertainty and complexity are common properties of transport systems, especially when the systems cover a long geographic distance and a long period of time. Shipping is further subject to uncertain, diverse and changing national and international regulations.

\subsection{Digitalization}

Container shipping enables intermodal transportation, with the same container being transported by different transport vehicles and handled by different material handling equipment in the end-to-end CSSC. Intuitively, container transport is a perfect example for the realization of vertically integrated supply chains. However, in reality container transport is extremely fragmented. For example, Maersk Line reported that a container shipment transported from Kenya to the Netherlands involved 30 different parties and more than 200 pieces of documentation [3]. The involved companies are often very different in terms of the use of information technologies. Some companies may be technologically advanced, whereas others are manual and struggling with the basic electronic transactions. However, the performance of a supply chain is determined by the weakest link in the supply chain. 
The fragmentation of container shipping is worsened by the long-standing scheduling unreliability and port congestion. According to Sea-Intelligence, the average delay time for ships' arrivals at container ports was 3-4 days for every year between 2012 and 2018 [3]. Due to the cascading effect, when a vessel is delayed at one port, it is likely to be delayed at the next port. Schedule unreliability not only causes serious financial consequences (e.g., inventory costs and production stoppage to shippers, and rescheduling and extra work to terminal operators), but also increases the distrust between supply chain members. Notteboom [115] conducted an empirical study and showed that port and terminal-related factors such as port congestion and uncertain handling time accounted for over 93\% of sources of schedule unreliability. In fact, port congestion has been an industry-wide problem recently. In the UK, the three largest container ports, Felixstowe, Southampton, and London Gateway, experienced severe congestion in the second half of 2020. As a result, the inland logistics sector even called for help from the UK government to tackle the port congestion issue at three ports, because it delayed container cargoes, diverted ships from the UK and hiked costs for shippers and freight forwarders [116]. Southern Californian ports (Los Angeles and Long Beach) were suffering from near-record levels of congestion, which forced many arriving ships to anchor for up to 12 days before being able to dock at ports [117]. Persistent schedule unreliability and frequent port congestion damage the relationships between stakeholders in the CSSC.

The fragmentation of container shipping is further worsened by the non-committal relationships between shipping lines and shippers. According to Maersk Line and HapagLloyd, 25\% of slot bookings did not show up, which is called the no-show phenomenon [118]. On the other hand, shippers may not get the booked containers shipped as agreed because shipping lines can rollover the booked slots to the next week due to the overbooking behaviour. The current common practice in the container shipping industry is no penalty for either party for no-show or rollover. A couple of shipping lines such as Maersk have made efforts to move in the direction of enforceable contracts between shipping lines and shippers [119]. However, it is debatable whether the problem could be solved by imposing penalties in the booking contracts. A more fundamental reason is the culture of the shipping industry regarding business processes [118], which lacks accuracy, reliability, transparency and visibility (e.g., error rates in billing, unreliable schedule, changes in sailings or port calls, real-time notifications). In this regard, digital technologies such as big data, machine learning, artificial intelligence, and optimization can enable greater automation and visibility to achieve better performance of the CSSC.

Feibert et al. [120] reviewed the extant literature from the integrated digitalization and business process management perspective. Four themes are identified according to whether digital technology or business process management can enhance the efficiency or responsiveness of the supply chain performance. Egloff et al. [121] identified seven digital technologies that are contributing to ocean carriers' performance improvement and transforming container shipping. The seven digital trends are E-platforms, advanced analytics, Internet of Things (IoT), AI, autonomous vessels and robotics, blockchain, and cyber security, which influence four core processes/areas: planning, operations, commercial and support functions. A holistic approach to the digital transformation of container shipping is presented ranging from strategic vision to digitalized core processes/activities, then to the fundamental enablers. Lambrou et al. [122] presented a baseline conceptual model of shipping digitalization, which consists of three pillars: (i) digital technologies (e.g., IoT, Data analytics, AI, Blockchain); (ii) digital solutions (e.g., Predictive maintenance; Shipping personal assistant; Logistics and trade smart contracts); and (iii) digitalization management practices (e.g., Digital partnerships; Strategic thinking; Digital mindset and skillset; Digitalization resourcing). Yang [123] conducted a questionnaire survey on the blockchain applications in the maritime shipping supply chain. It was found that customs clearance and management, digitalizing and easing paperwork, standardization and platform development dimensions are positively related to the intention to use blockchain. Anwar et al. [124] provided a comprehensive literature review on the applications of digital 
technologies for logistics operations management at container terminals. They found that over $94 \%$ of relevant studies focused on AI, $29 \%$ discussed IoT and Cloud Computing technologies, and there was very little research on Blockchain at container terminals.

Based on the literature, we propose a pathway towards CSSC digitalization from two aspects across all the logistics segments in CSSC: digital technology application in business processes, and behaviour and relationship in the supply chain, as shown in Figure 1. In previous sections, we have introduced five main logistics segments in CSSC including freight logistics, container logistics, vessel logistics, port/terminal logistics, and inland transport logistics. It is essential to digitalize each segment in terms of their business processes. The core business processes may be divided into two broad categories: the commercial processes and the operations processes [121]. The commercial processes include activities such as booking, billing, payment, customization, customs clearance, tracking \& tracing, insurance, and claims. The operations processes include the main planning and control activities that we have mentioned in previous sections which may differ in different logistics segments.

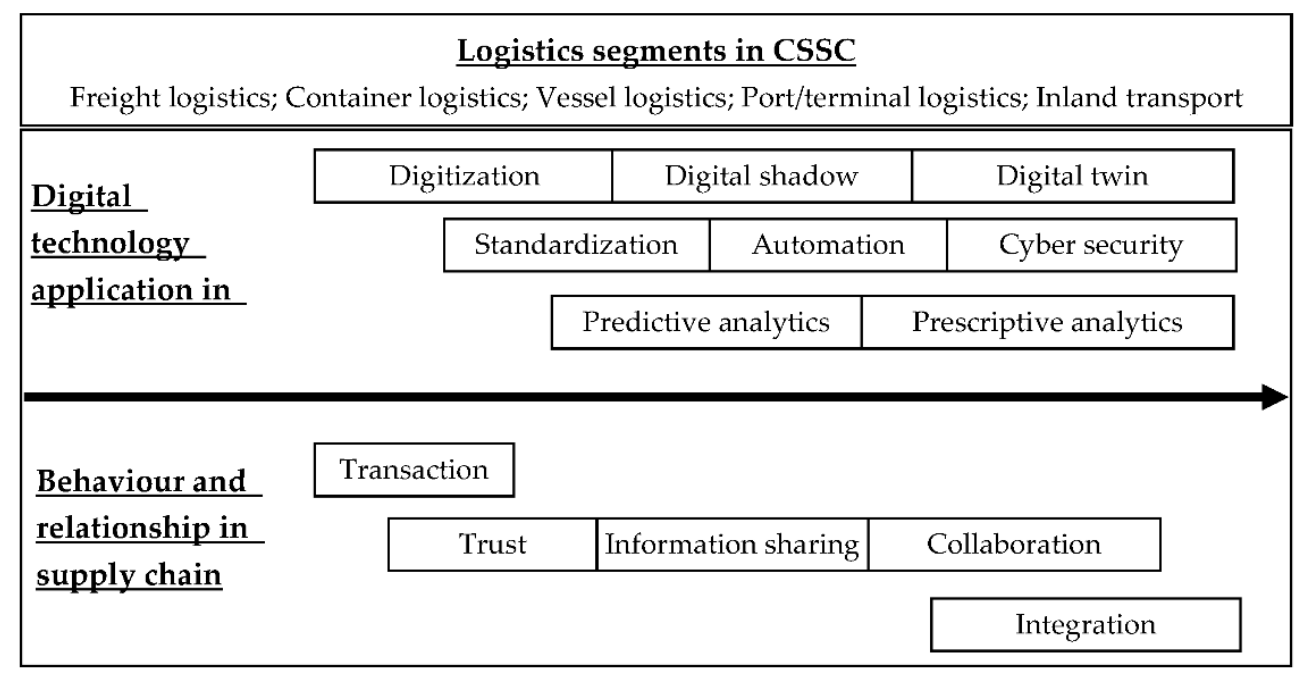

Figure 1. A pathway towards CSSC digitalization.

From the business process perspective, CSSC digitalization requires the applications of various digital technologies in multiple steps (that are overlapping to some extent), which can be explained as follows:

- Digitization: refers to the process of converting information from a physical format to a digital one. Container shipping is a data-intensive business. It involves a significant amount of paperwork such as export documents, bills of lading, cargo manifests, invoices and receipts. Converting non-digital into digital representation requires the application of digital tools such as computer systems, e-platforms, and distributed ledger (blockchain). On the other hand, new data regarding the states of containers, handling equipment and transport vehicles should be collected through sensors, Internet of Things, 5G and AIS (automatic identification system).

- Digital shadow: refers to the representation of a physical system or object in digital form including all the data associated with the system/object. For digital shadow, there is an automatic information flow from the physical world to the digital representation, but not in the opposite direction.

- Digital Twin: refers to the digital (virtual) replication of a physical system/object emphasizing the bi-directional automatic information flow between the physical world and digital replication on a real time basis. This digital replication can be used to test new strategies and designs without wasting physical resources and feed the results into the physical world on a real time basis. 
- Standardization: the early success of containerization is largely due to the standardization of shipping containers (twenty-equipment unit and forty-equipment unit boxes) so that all transport vehicles and handling equipment in the CSSC can be purposely designed to carry and handle the standardized containers efficiently. Standardization is the pre-requisite of automation. There is a need to standardize the business processes and logistics activities, where machines and robots perform better than humans.

- Automation: reduces or eliminates the need for human intervention and therefore improves operational efficiency and minimizes human errors. Robotic technology has been used to automate certain port business processes including loading and discharging ships, stacking and reshuffling containers, and operating gates, e.g., in Rotterdam and Qingdao. Autonomous ships navigate waters with little or no human interaction, where onboard computer systems monitor and manage navigation. The challenge of automation is the handling of exceptions in which human beings are usually better than machines. The regulatory constraint is another barrier for autonomous ships.

- Cyber security: concerns the protection of the internet-connected systems including hardware, software and data from malicious attacks to ensure the integrity, confidentiality, and availability of digital information. In the shipping industry, the four largest shipping lines in the world have been hit by cyber-attacks since 2017. Maersk was shut down for weeks by the NotPetya ransomware/wiper in 2017; COSCO was taken down for weeks by ransomware in 2018; MSC's data center was brought down for days by an unnamed malware in 2020; and CMA CGM was hit by a ransomware attack and forced to take down its booking system in 2020. As digitization and automation progress, cyber security is receiving more attention.

- Predictive analytics: takes historical data from various sources and uses machine learning to train prediction models so that the model can predict what will happen in the future. Predictive analytics essentially uses a set of attributes of the data object to predict the likelihood of an unknown future outcome. This step is related to data mining, machine learning and artificial intelligence. Common techniques include classification, regressions, decision tree-based methods, support vector machine, Bayes algorithms, and neural networks.

- Prescriptive analytics: takes the results from predictive analytics and the various business rules into an optimization model to determine the best decisions and policies by optimizing the objective functions. This step takes a systematic approach using techniques such as mathematical programming, simulation and heuristics, which aims to systematically leverage the power of advanced analytics and artificial intelligence to improve the performance of business processes.

From the supply chain relationship perspective, CSSC digitalization requires a change of behaviors and mindset in the relevant stakeholders, moving from transactional relationships towards integrative relationships, which can be explained as follows:

- Transaction: refers to the exchange or transfer of goods, services, or funds. A transactional relation is often called an arm's length relationship, where price is the primary concern for two parties. The transactional relation can be a single and repeated transactions. Nevertheless, this type of relation is characterized by distrust, competition and conflict.

- Trust: refers to a range of observable behaviors and a cognitive state that encompasses predictability [125]. The predictability can be interpreted as the carrier's reliability to deliver on time, a terminal's handling reliability, or a shipper' ability to make the laden container ready for loading onto vessels or to return empty containers on time. Trust is built on the information regarding whether and to what degree players keep their promises to each other within the CSSC. Trust is regarded as an essential element for successful supply chain partners' relationship.

- Information sharing: indicates the exchange of data between processes or channel members. In the shipping industry, data is kept in silos. Even within a single shipping 
company, operational data (e.g., container and vessel movements) and financial data (e.g., invoices, contracts and freight rates) are kept separately in different applications. There is a need to connect multiple data sources using cloud IT. Information sharing between channel members is more difficult, mainly due to the proprietary data, and partially due to the non-portable or non-digital format of the data. Information sharing is a crucial step for supply chain visibility. It is regarded as an antecedent of collaborative channel relationships.

- Collaboration: is defined as working jointly or cooperating with channel members for mutual benefit. Collaborative channel members not only share information, but also coordinate decision making with a common goal in mind. In multimodal container transport, shipping lines often collaborate with inland carriers to secure smooth container transfer between seaborne transport and inland transport, e.g., the longterm contractual relationship between Maersk Line and Freightliner in the UK.

- Integration: refers to the incorporation of the business processes at different positions in the marketing channel. Integrative relationships include merger and acquisition, joint venture, and vertical integration. Integration is characterized by long-term partnership and mutually shared goals. Shipping lines have tried to integrate CSSC to some degree by expanding their business processes into terminal operations and inland logistics. For example, major shipping lines like Maersk, Cosco and Evergreen, are operating dedicated container terminals through leasing or joint venture with terminal operators. Maersk Line followed a container logistics integrator strategy by expanding its logistics operations. This led to a significant increase of revenue share in logistics from its top 200 ocean customers, which showed the commercial synergies between ocean transport and inland logistics [126].

\subsection{Decarbonization}

Carbon dioxide, as one of the most important greenhouse gases (GHG) emitted by human activities, has attracted IMO's attention for many years. IMO has sponsored four extensive studies on GHG emissions from shipping, which were published in 2000, 2009, 2014 and 2020, respectively. Among all the shipping sectors, container ships are the largest source of $\mathrm{CO}_{2}$ emissions, accounting for $23 \%$ of the total $\mathrm{CO}_{2}$ emissions from shipping [127]. According to the Paris Climate Summit in 2016, the GHG emissions from shipping will remain unregulated at least until 2023. However, it is well known that decarbonization has been on the agenda of IMO. The shipping industry and member states in IMO have been debating the various measures to reduce GHG from shipping in recent years.

Maritime emission reduction measures can be classified into four categories: operational measures, technical measures, market-based measures, and alternative fuels [3,128,129]. Operational measures focus on reducing energy consumption and improving operational productivity by performing appropriate operational activities for ships or ship-related equipment such as enhanced engine maintenance, better logistics and fleet planning, energy-saving at ports, and ship and container recycling and reusing. Technical measures focus on enhancing the energy efficiency by hardware improvements of the ship or the ship-related equipment, e.g., engine, hull, propeller, bulbous bow. Market-based measures impose monetary incentives or penalties to force shipping stakeholders to reduce emissions, e.g., attaching a price to emissions via taxes/levies, or cap-and-trade. A variety of marketbased measures have been proposed by different member states of IMO. However, there is no agreed market-based measures yet [130]. Alternative fuels refer to low-carbon and zero-carbon fuels to power ships, which is an essential step to achieve the IMO's longterm target, i.e., reducing GHG emissions by 50\% in volume compared to 2008 levels by 2050. At present, various alternative fuels have been researched and assessed including liquified natural gas (LNG), biofuels, hydrogen, ammonia, methanol, nuclear, wind, solar, and shore-to-ship power [3]. However, not all are suitable for container shipping.

In 2018, IMO published an initial GHG strategy to decarbonize shipping, which specified short-term, medium-term, and long-term measures. The short-term measures promote 
technical and operational measures to reduce GHG emissions from ships up to 2023. The medium-term measures seek further operational measures and introduce marketbased methods and low-carbon or zero-carbon fuels, with the aim of reducing carbon intensity by $40 \%$ by 2030 compared to 2008 levels. The long-term measures urge the deployment of zero-carbon or fossil-free fuels for ships with the aim to reduce carbon intensity by $70 \%$ in 2050 compared to 2008 levels [131].

Following the IMO ambitions in the Initial GHG Strategy, DNV GL conducted a number of scenario analysis and estimated a pathway of maritime fuel mix in Table 4, where e- indicates an electro-fuel based on 'green'-hydrogen that can be synthesized from nitrogen and hydrogen in an electrochemical process [132]. Table 4 forecasts the share of different types of engine and fuel system that would be installed in the ship fleet in the years 2030, 2040 and 2050. It can be seen that very low sulphur fuel oil/marine gas oil (VLSFO/MGO) is the primary fuel up to 2030, while the uptake of LNG continues until 2040. From 2040, there is a transition to ammonia, which will be the primary fuel in 2050. However, DNV GL also conducted another set of scenario analyses by following the ambition of decarbonization by 2040 , which led to a very different pathway, in which biomethanol would occupy $8 \%, 63 \%$ and $81 \%$ market share in 2030, 2040 and 2050, respectively, whereas LNG and VLSFO/MGO would account for $28 \%$ each in 2030, but phase out from 2040.

Table 4. A pathway of maritime fuel mix towards IMO goals.

\begin{tabular}{cccc}
\hline \% of Energy & $\mathbf{2 0 3 0}$ & $\mathbf{2 0 4 0}$ & $\mathbf{2 0 5 0}$ \\
\hline VLSFO/MGO & $46 \%$ & $12 \%$ & $1 \%$ \\
LNG & $25 \%$ & $48 \%$ & $19 \%$ \\
Heavy fuel oil & $17 \%$ & $10 \%$ & $0 \%$ \\
e-MGO & $10 \%$ & $10 \%$ & $23 \%$ \\
e-LNG & $2 \%$ & $3 \%$ & $3 \%$ \\
e-ammonia & $0 \%$ & $10 \%$ & $40 \%$ \\
bio-LNG & $0 \%$ & $5 \%$ & $11 \%$ \\
e-methanol & $0 \%$ & $2 \%$ & $3 \%$ \\
\hline
\end{tabular}

One hot topic recently is the debate on whether LNG could be a transition fuel. The report issued by the World Bank stated that LNG is not suitable as a transitional fuel in decarbonizing shipping and suggested that new public policy supporting LNG as a bunker fuel should be avoided and existing support policies should be reconsidered [133]. As a fossil fuel, LNG will not be a long-term solution in shipping decarbonization. However, LNG is the cleanest fossil fuel and is technologically more readily available to power ships. A recent survey showed that a majority of shipowners regarded LNG as the most likely potential fuel for decarbonizing shipping and meeting the IMO emission goals [134]. In fact, some shipping lines have already ordered and deployed LNG-powered container ships. For example, CMA CGM deployed the world's largest container ship powered by LNG on the Asia-Europe service route in September 2020. However, industrial leaders hold different views on the role of LNG in shipping decarbonization. For example, Maersk openly stated that LNG did not have a role to play and questioned why the shipping industry would invest so much on expensive LNG-fueled vessels and new logistics infrastructure only to secure marginal lifecycle emission gains and risk methane slip form burning LNG. Instead, Maersk proposed four types of fuel as potential pathways to net zero emission: biodiesel, methanol, ammonia, and lignin fuels (based on lignin-alcohol blends). On the other hand, Wartsila, a global leader in technology solutions for marine and energy markets, argued that "LNG propulsion can offer more flexibility to future conversions on ships to run on low carbon fuels" and "there were ongoing efforts to minimize the methane slip level" [135].

The selection of fuel systems for ship engines is a trade-off over a wide range of determinant factors, e.g., cost-benefit analysis, $\mathrm{CO} 2$ and other emissions, the technology readiness level, the logistics infrastructure, the availability of fuel supply, and the IMO 
regulation timelines. Table 5 summarizes the main types of shipping fuel in relation to decarbonization and the determinant factors for fuel choice, where carbon neutral means that the carbon emissions caused are balanced out by removing an equivalent amount of carbon from the atmosphere (called offsetting); and zero carbon means no carbon dioxide to be added to the atmosphere during the service and in the production. However, the differences between carbon neutral fuels and carbon zero fuels are often blurred.

Table 5. Characteristics of fuel types and choice determinants for container ships.

\begin{tabular}{cl}
\hline Low-carbon fuels & Petroleum-based fuels with carbon capture and sequestration \\
& systems; LNG; LPG; Methanol; Ethanol; Biofuel \\
\hline \multirow{3}{*}{ Carbon-neutral fuels } & Bio-MGO; e-MGO; Bio-LNG; e-LNG; Synthetic fuels by \\
& hydrogenating carbon dioxide; Biofuels through photosynthesis; \\
& Renewable natural gas; Renewable diesel fuel \\
\hline Zero-carbon fuels & Hydrogen; e-ammonia; Bio-methanol; e-methanol; Fuels \\
& produced from renewable electricity, biomass and natural gas \\
& with CCS \\
\hline & Economic performance: Commercial interest of stakeholders; \\
& Future price of energy sources (renewable electricity, natural gas \\
& and biomass); Future fuel prices; Energy density; \\
& Compatibility with conventional marine engines \\
& Environmental considerations: CO 2 emission; other emissions \\
& (SOx/NOx, particulate matters); life cycle emission \\
& Regulations and policies: International, regional, national and \\
& even port-based emission regulations and policies; Safety \\
& regulations; Market-based measures; Entering into force over \\
& short and medium term; \\
& Technology considerations: Technology readiness level; Safety \\
and security; Ship design technology; Technology for generating & power; Engine technologies; \\
Operational measures: Ship types and sizes; Trade routes; \\
Digitalization to reduce GHG; Transport modal shift; Ability to \\
comply with regulations; \\
Logistics considerations: Fuel supply infrastructure; Fuel \\
availability; Fuel storage and transport; Ship re-fuelling \\
\hline
\end{tabular}

The challenge is that shipowners have very limited time to determine this longterm decision (noting a new ship has about 25 years life cycle). Given the diverse views from industrial leaders and a wide range of determinant factors, it is likely that different companies will take different pathways towards a net carbon zero future. In this regards, interesting research opportunities associated with CSSC decarbonization include:

- Manage decarbonization risks considering technological, safety, regulatory, availability, price uncertainties in container shipping. This may require multi-stage dynamic approaches considering that information is likely to update over time and decisions are made sequentially.

- Develop decarbonization strategies by appropriately integrating technical measures, operational measures, market-based measures, and alternative fuels. A holistic and simulation-based method may be applied in this direction.

- Select the mix of fuel types and technology systems in the heterogenous ship fleet in different trade routes. Research methods from ship fleet sizing and deployment could be adapted to this direction by considering the unique characteristics of different types of future fuels.

- Evaluate the impact of decarbonization regulations that may come into force at different points of time with different requirements. In this regard, a multi-period dynamic game model could be applied.

- Establish and manage the logistics networks of new fuels including constructing infrastructure and matching supply with demand, e.g., HMM, the South Korea shipping 
line, has started to develop an ammonia fuel supply chain for shipping. This topic may take the fuel supply's perspective.

- Redesign the shipping service network considering maritime fuel mix and its availability at ports. Determine ship re-fueling strategies under the new maritime fuel mix. Up to now, the primary fuel used in the shipping sector is heavy fuel oil (HFO) and low sulphur fuel oils (LSFO). Their availability is universal and sufficient in most ports. Taking the fuel demand's perspective, shipping lines have to redesign the shipping service network and the fuel management system considering a more limited and constrained supply of new fuel.

- Shift road container traffic to rail or barge transport mode to decarbonize inland container transport, which may require investment and collaboration between shipping lines and rail/barge operators, and/or subsidy from governments and local councils. - Combine decarbonization with digitalization in CSSC. It is believed that digitalization is a key enabler in the process of CSSC decarbonization. In particular, digital technologybased operational measures are essential to achieve green shipping and green ports.

Ports are known as concentration areas producing air pollutants and GHG emissions. Since ports are usually located near highly populated coastal cities, air pollutants at ports have direct impacts on local society. Many countries and regions have imposed regulations on air quality standards in areas surrounding ports. However, most countries do not issue specific regulations on GHG emission standards for the port and maritime sectors. The IMO's initial GHG strategy in 2018 did not explicitly include the emissions from port activities or domestic vessels operating in port areas [136]. Therefore, there is a need of more regulatory and operational effort to decarbonize port emissions.

Port emissions are generated from the stationary type of source and the mobile type of source. The stationary type includes electrical grid, power plant, industrial facilities, manufacturing facilities and administrative offices. The mobile type includes ocean-going vessels, domestic vessels, cargo handling equipment, internal and external trucks, and rail locomotives. It is known that trucks, ocean-going vessels and cargo handling equipment account for over $90 \%$ of $\mathrm{CO}_{2}$ emissions from the mobile type of source at ports. Port emissions reduction measures may be categorized into four groups: technical measures, operational measures, alternative fuels or energy sources, and structural changes $[137,138]$. Similar to ship decarbonization, the diversity of ports in terms of viewpoints, capability, governance, and geographic location and the pathways to decarbonize ports will probably differ case by case.

\section{Conclusions}

In this paper, taking the logistics perspective, we provide an overview of the container shipping supply chain (CSSC) covering all major logistics segments including freight logistics, container logistics, vessel logistics, port/terminal logistics, and inland transport logistics. The main planning problems and research opportunities in each logistics segment are reviewed and discussed. Moreover, the two most important challenges that CSSC is facing recently, digitalization and decarbonization, are discussed in detail.

This paper contributes to the literature by: (i) providing a more complete and coherent view of the container shipping supply chain and the main operations management problems of five logistics segments in the end-to-end CSSC, pointing out the specific research opportunities in each of five individual logistics segments; (ii) raising the awareness of the extremely fragmented phenomenon of CSSC by emphasizing the issues of schedule unreliability, port congestion, no-show and rollover as the underlying reasons; (iii) discussing the digitalization challenge and proposing a pathway towards CSSC digitalization. Specifically, we believe that CSSC digitalization requires the application of digital technologies in various business processes across five logistics segments, and a change in behaviors and relationships in the supply chain; (iv) discussing the decarbonization challenge that will have a fundamental impact on the shipping industry in the next two decades. It is argued that shipping decarbonization is likely to take diverse pathways with different 
fuel/energy systems for ships and ports. The determinant factors for fuel choice are summarized. A range of research opportunities associated with shipping decarbonization is provided. In summary, by presenting the research opportunities and urgent challenges to the CSSC, this study stimulates interested researchers to tackle these challenging issues and push forward the knowledge frontier. It may also help bridge the gap between researchers who are experts in one or two segments of the CSSC but are less familiar with other segments of the CSSC so that they can extend their research scopes, work collaboratively, and integrate different planning problems from the perspective of CSSC management.

This study has a number of limitations for further research. First, due to the broad coverage of the CSSC, this paper is not able to include all relevant studies in the mentioned five logistics segments. Nevertheless, up-to-date survey papers and the representative research papers in each logistics segment of CSSC have been included. There are also some logistics segments that are associated with CSSC but not covered in this paper, e.g., multimodal transport and reverse logistics (including ship recycling). Further research could be pursued in these directions. Second, this review paper does not provide a guideline on how to tackle the identified research gaps (research opportunities), although some potential solution methods have been suggested, or could be borrowed from the existing literature (and the references therein) reviewed in this study. This is because many research gaps identified in this paper are open questions and have not been adequately investigated. They may require the development of innovative research methods. Third, we did not explicitly rank the relative importance of the identified research opportunities. The research gaps presented in individual segments are largely oriented to the specific logistics segment. The topics of digitalization and decarbonization are relatively generic and not associated with a specific logistics segment in CSSC. In fact, the topics of digitalization and decarbonization can be regarded as CSSC-oriented. All logistics segments in the CSSC are facing the challenges of digitalization and decarbonization. Many research gaps in the individual segments could be better solved with the development of digitization and decarbonization. In this regard, an empirical research such as questionnaire surveys would be helpful to evaluate and compare the relative importance of the identified research gaps.

Funding: This study is partially supported by the Royal Society (Grant No. IEC $\backslash$ NSFC $\backslash 170100$ ).

Institutional Review Board Statement: Not applicable.

Informed Consent Statement: Not applicable.

Data Availability Statement: Not applicable.

Conflicts of Interest: The authors declare no conflict of interest.

\section{References}

1. MergeGlobal. Insomnia-Why challenges facing the world container shipping industry make for more nightmares than they should. Am. Shipp. 2008, 7, 68-85.

2. Lee, C.-Y.; Song, D.-P. Ocean container transport in global supply chains: Overview and research opportunities. Transp. Res. Part B Methodol. 2017, 95, 442-474. [CrossRef]

3. Song, D.P. Container Logistics and Maritime Transport; Routledge: London, UK, 2021.

4. UNCTAD. Development of Multimodal Transport and Logistics Services; The UNCTAD Secretariat: Geneva, Switzerland, 2003.

5. Agbo, A.A.; Li, W.; Atombo, C.; Lodewijks, G.; Zheng, L. Feasibility study for the introduction of synchromodal freight transportation concept. Cogent Eng. 2017, 4, 1305649. [CrossRef]

6. Verweij, K. Synchronic modalities: Critical success factors. In Logistics Handbook 2011; Van der Sterre, P.J., Ed.; Feico Houweling: Rotterdam, The Netherlands, 2011; pp. 75-92.

7. Pfoser, S.; Treiblmaier, H.; Schauer, O. Critical Success Factors of Synchromodality: Results from a Case Study and Literature Review. Transp. Res. Procedia 2016, 14, 1463-1471. [CrossRef]

8. Giusti, R.; Manerba, D.; Bruno, G.; Tadei, R. Synchromodal logistics: An overview of critical success factors, enabling technologies, and open research issues. Transp. Res. Part E Logist. Transp. Rev. 2019, 129, 92-110. [CrossRef]

9. Liu, Z.; Meng, Q.; Wang, S.; Sun, Z. Global intermodal liner shipping network design. Transp. Res. Part E Logist. Transp. Rev. 2014, 61, 28-39. [CrossRef] 
10. Shibasaki, R.; Iijima, T.; Kadono, T.; Shishido, T.; Kawakami, T. Network assignment model of integrating maritime and hinterland container shipping: Application to Central America. Marit. Econ. Logist. 2017, 19, 234-273. [CrossRef]

11. Halim, R.A.; Tavasszy, L.A.; Seck, M.D. Modeling the global freight transportation system: A multi-level modeling perspective. In Proceedings of the Winter Simulation Conference, Berlin, Germany, 9-12 December 2012.

12. Huang, Y.; Rashidi, T.H.; Gardner, L. Modelling the global maritime container network. Marit. Econ. Logist. 2018, 20, 400-420. [CrossRef]

13. Sinha-Ray, P.; Carter, J.; Field, T.; Marshall, J.; Polak, J.; Schumacher, K.; Song, D.; Woods, J.; Zhang, J. Container World: Global agent-based modelling of the container transport business. In Proceedings of the 4th International Workshop on AgentBased Simulation, Montpellier, France, 28-30 April 2003.

14. Caschili, S.; Medda, F.R. A Review of the Maritime Container Shipping Industry as a Complex Adaptive System. Interdiscip. Descr. Complex Syst. 2012, 10, 1-15. [CrossRef]

15. Henesey, L.E.; Davidsson, P.; Persson, J.A. Agent based simulation architecture for evaluating operational policies in transhipping containers. Auton. Agents Multi-Agent Syst. 2009, 18, 220-238. [CrossRef]

16. Winikoff, M.; Wagner, H.F.; Young, T.; Cranefield, S.; Jarquin, R.; Li, G.; Martin, B. Agent-Based Container Terminal Optimisation. In Multiagent System Technologies. MATES 2011. Lecture Notes in Computer Science; Klugl, F., Ossowski, S., Eds.; Springer: Berlin/Heidelberg, Germany, 2011; Volume 6973, pp. 137-148.

17. Rizaldi, A.; Wasesa, M.; Rahman, M.N. Yard Cranes Coordination Schemes for Automated Container Terminals: An Agent-based Approach. Procedia Manuf. 2015, 4, 124-132. [CrossRef]

18. Henesey, L.E. Improved inter terminal transportation using agent technology. In Proceedings of the 30th Annual Workshop of the Swedish Artificial Intelligence Society, Karlskrona, Sweden, 15-16 May 2017; pp. 60-67.

19. Song, D.P.; Dong, J.X. Empty container repositioning. In Handbook of Ocean Container Transport Logistics-Making Global Supply Chain Effective; Lee, C.Y., Meng, Q., Eds.; Springer: New York, NY, USA, 2015; pp. 163-208.

20. Braekers, K.; Janssens, G.K.; Caris, A. Challenges in Managing Empty Container Movements at Multiple Planning Levels. Transp. Rev. 2011, 31, 681-708. [CrossRef]

21. Kuzmicz, K.A.; Pesch, E. Approaches to empty container repositioning problems in the context of Eurasian intermodal transportation. Omega 2019, 85, 194-213. [CrossRef]

22. Shen, W.; Khoong, C. A DSS for empty container distribution planning. Decis. Support Syst. 1995, 15, 75-82. [CrossRef]

23. Song, D.P.; Dong, J.X. Flow balancing-based empty container repositioning in typical shipping service routes. Marit. Econ. Logist. 2011, 13, 61-77. [CrossRef]

24. Cheung, R.K.; Chen, C.-Y. A Two-Stage Stochastic Network Model and Solution Methods for the Dynamic Empty Container Allocation Problem. Transp. Sci. 1998, 32, 142-162. [CrossRef]

25. Erera, A.L.; Morales, J.C.; Savelsbergh, M. Robust Optimization for Empty Repositioning Problems. Oper. Res. 2009, 57, 468-483. [CrossRef]

26. Brouer, B.D.; Pisinger, D.; Spoorendonk, S. Liner shipping cargo allocation with repositioning of empty containers. INFOR 2011, 49, 109-124. [CrossRef]

27. Song, D.-P.; Dong, J.-X. Cargo routing and empty container repositioning in multiple shipping service routes. Transp. Res. Part B Methodol. 2012, 46, 1556-1575. [CrossRef]

28. Chao, S.L.; Chen, C.C. Applying a time-space network to reposition reefer containers among major Asian ports. Res. Trans. Bus. Manag. 2015, 17, 65-72. [CrossRef]

29. Di Francesco, M.; Crainic, T.G.; Zuddas, P. The effect of multi-scenario policies on empty container repositioning. Transp. Res. Part E Logist. Transp. Rev. 2009, 45, 758-770. [CrossRef]

30. Di Francesco, M.; Lai, M.; Zuddas, P. Maritime repositioning of empty containers under uncertain port disruptions. Comput. Ind. Eng. 2013, 64, 827-837. [CrossRef]

31. Moon, I.-K.; Ngoc, A.-D.D.; Hur, Y.-S. Positioning empty containers among multiple ports with leasing and purchasing considerations. OR Spectr. 2010, 32, 765-786. [CrossRef]

32. Long, Y.; Lee, L.H.; Chew, E.P. The sample average approximation method for empty container repositioning with uncertainties. Eur. J. Oper. Res. 2012, 222, 65-75. [CrossRef]

33. Moon, I.; Ngoc, A.-D.D.; Konings, R. Foldable and standard containers in empty container repositioning. Transp. Res. Part E Logist. Transp. Rev. 2013, 49, 107-124. [CrossRef]

34. Myung, Y.-S. Efficient solution methods for the integer programming models of relocating empty containers in the hinterland transportation network. Transp. Res. Part E Logist. Transp. Rev. 2017, 108, 52-59. [CrossRef]

35. SteadieSeifi, M.; Dellaert, N.; Nuijten, W.; Van Woensel, T. A metaheuristic for the multimodal network flow problem with product quality preservation and empty repositioning. Transp. Res. Part B Methodol. 2017, 106, 321-344. [CrossRef]

36. Shintani, K.; Konings, R.; Imai, A. Combinable containers: A container innovation to save container fleet and empty container repositioning costs. Transp. Res. Part E Logist. Transp. Rev. 2019, 130, 248-272. [CrossRef]

37. Li, J.-A.; Liu, K.; Leung, S.C.; Lai, K.K. Empty container management in a port with long-run average criterion. Math. Comput. Model. 2004, 40, 85-100. [CrossRef]

38. Song, D.-P.; Zhang, Q. A Fluid Flow Model for Empty Container Repositioning Policy with a Single Port and Stochastic Demand. SIAM J. Control. Optim. 2010, 48, 3623-3642. [CrossRef] 
39. Zhang, B.; Ng, C.T.; Cheng, T.C.E. Multi-period empty container repositioning with stochastic demand and lost sales. J. Oper. Res. Soc. 2014, 65, 302-319. [CrossRef]

40. Legros, B.; Bouchery, Y.; Fransoo, J. A Time-Based Policy for Empty Container Management by Consignees. Prod. Oper. Manag. 2019, 28, 1503-1527. [CrossRef]

41. Song, D.-P. Characterizing optimal empty container reposition policy in periodic-review shuttle service systems. J. Oper. Res. Soc. 2007, 58, 122-133. [CrossRef]

42. Lam, S.-W.; Lee, L.-H.; Tang, L.-C. An approximate dynamic programming approach for the empty container allocation problem. Transp. Res. Part C Emerg. Technol. 2007, 15, 265-277. [CrossRef]

43. Shi, N.; Xu, D. A Markov decision process model for an online empty container repositioning problem in a two-port fixed route. Int. J. Oper. Res. 2011, 8, 8-17.

44. Ng, C.T.; Song, D.-P.; Cheng, E. Optimal Policy for Inventory Transfer between Two Depots with Backlogging. IEEE Trans. Autom. Control. 2012, 57, 3247-3252. [CrossRef]

45. Li, J.-A.; Leung, S.C.; Wu, Y.; Liu, K. Allocation of empty containers between multi-ports. Eur. J. Oper. Res. 2007, 182, 400-412. [CrossRef]

46. Song, D.-P.; Dong, J.-X. Empty Container Management in Cyclic Shipping Routes. Marit. Econ. Logist. 2008, 10, 335-361. [CrossRef]

47. Dong, J.X.; Song, D.P. Container fleet sizing and empty repositioning in liner ship-ping systems. Trans. Res. Part E 2009, 45, 860-877. [CrossRef]

48. Song, D.-P.; Dong, J.-X. Effectiveness of an empty container repositioning policy with flexible destination ports. Transp. Policy 2011, 18, 92-101. [CrossRef]

49. Budipriyanto, A.; Novianti, M.D.; Susanto, T. Empty container reposition using max-min review system: Simulation approach. IOP Conf. Ser. Mater. Sci. Eng. 2021, 1072, 012048. [CrossRef]

50. Lee, L.H.; Chew, E.P.; Luo, Y. Empty container management in multi-port system with inventory-based control. Int. J. Adv. Syst. Meas. 2012, 5, 164-177.

51. Yun, W.Y.; Lee, Y.M.; Choi, Y.S. Optimal inventory control of empty containers in inland transportation system. Int. J. Prod. Econ. 2011, 133, 451-457. [CrossRef]

52. Dang, Q.-V.; Nielsen, I.E.; Yun, W.-Y. Replenishment policies for empty containers in an inland multi-depot system. Marit. Econ. Logist. 2013, 15, 120-149. [CrossRef]

53. Epstein, R.; Neely, A.; Weintraub, A.; Valenzuela, F.; Hurtado, S.; Gonzalez, G.; Beiza, A.; Naveas, M.; Infante, F.; Alarcon, F.; et al A Strategic Empty Container Logistics Optimization in a Major Shipping Company. Interfaces 2012, 42, 5-16. [CrossRef]

54. Xing, X.; Drake, P.R.; Song, D.; Zhou, Y. Tank Container Operators' profit maximization through dynamic operations planning integrated with the quotation-booking process under multiple uncertainties. Eur. J. Oper. Res. 2019, 274, 924-946. [CrossRef]

55. Wolff, J.; Herz, N.; Flamig, H. Report on Empty Container Management in the Baltic Sea Region: Experiences and Solutions from a Multi-Actor Perspective; The Baltic Sea Region Programme 2007-2013; Hamburg University of Technology: Hamburg, Germany, 2011.

56. Heaver, T.; Meersman, H.; Moglia, F.; Van De Voorde, E. Do mergers and alliances influence European shipping and port competition? Marit. Policy Manag. 2000, 27, 363-373. [CrossRef]

57. Panayides, P.M.; Cullinane, K. Competitive advantage in liner shipping: A review and research agenda. Int. J. Marit. Econ. 2002, 4, 189-209. [CrossRef]

58. Liu, J.; Wang, J. Carrier alliance incentive analysis and coordination in a maritime transport chain based on service competition. Transp. Res. Part E Logist. Transp. Rev. 2019, 128, 333-355. [CrossRef]

59. Notteboom, T.E. Container Shipping and Ports: An Overview. Rev. Netw. Econ. 2004, 3, 86-106. [CrossRef]

60. Cariou, P. Liner shipping strategies: An overview. Int. J. Ocean Syst. Manag. 2008, 1, 2-13. [CrossRef]

61. Frémont, A. Shipping Lines and Logistics. Transp. Rev. 2009, 29, 537-554. [CrossRef]

62. Zhu, S.; Zheng, S.; Ge, Y.-E.; Fu, X.; Sampaio, B.; Jiang, C. Vertical integration and its implications to port expansion. Marit. Policy Manag. 2019, 46, 920-938. [CrossRef]

63. Christiansen, M.; Fagerholt, K.; Ronen, D. Ship Routing and Scheduling: Status and Perspectives. Transp. Sci. 2004, 38, 1-18. [CrossRef]

64. Christiansen, M.; Fagerholt, K.; Nygreen, B.; Ronen, D. Ship routing and scheduling in the new millennium. Eur. J. Oper. Res. 2013, 228, 467-483. [CrossRef]

65. Brouer, B.D.; Alvarez, J.F.; Plum, C.E.M.; Pisinger, D.; Sigurd, M.M. A Base Integer Programming Model and Benchmark Suite for Liner-Shipping Network Design. Transp. Sci. 2014, 48, 281-312. [CrossRef]

66. Meng, Q.; Wang, S.; Andersson, H.; Thun, K. Containership Routing and Scheduling in Liner Shipping: Overview and Future Research Directions. Transp. Sci. 2014, 48, 265-280. [CrossRef]

67. Tran, N.K.; Haasis, H.-D. Literature survey of network optimization in container liner shipping. Flex. Serv. Manuf. J. 2013, 27, 139-179. [CrossRef]

68. Dulebenets, M.A.; Pasha, J.; Abioye, O.; Kavoosi, M. Vessel scheduling in liner shipping: A critical literature review and future research needs. Flex. Serv. Manuf. J. 2021, 33, 43-106. [CrossRef] 
69. Agarwal, R.; Ergun, Ö. Ship Scheduling and Network Design for Cargo Routing in Liner Shipping. Transp. Sci. 2008, 42, 175-196. [CrossRef]

70. Wang, T.; Wang, S.; Meng, Q. Liner Ship Fleet Planning: Models and Algorithms; Elsevier: Amsterdam, The Netherlands, 2018.

71. Qi, X.; Song, D.P. Minimizing fuel emissions by optimizing vessel schedules in liner shipping with uncertain port times. Trans. Res. Part E 2012, 48, 863-880. [CrossRef]

72. Wang, S.; Meng, Q. Liner ship route schedule design with sea contingency time and port time uncertainty. Transp. Res. Part B Methodol. 2012, 46, 615-633. [CrossRef]

73. Psaraftis, H.; Kontovas, C.A. Speed models for energy-efficient maritime transportation: A taxonomy and survey. Transp. Res. Part C Emerg. Technol. 2013, 26, 331-351. [CrossRef]

74. Psaraftis, H.; Kontovas, C.A. Ship speed optimization: Concepts, models and combined speed-routing scenarios. Transp. Res. Part C Emerg. Technol. 2014, 44, 52-69. [CrossRef]

75. $\mathrm{Ng}, \mathrm{M}$. Vessel speed optimisation in container shipping: A new look. J. Oper. Res. Soc. 2018, 70, 541-547. [CrossRef]

76. Fagerholt, K.; Laporte, G.; Norstad, I. Reducing fuel emissions by optimizing speed on shipping routes. J. Oper. Res. Soc. 2010, 61, 523-529. [CrossRef]

77. Ronen, D. The effect of oil price on containership speed and fleet size. J. Oper. Res. Soc. 2011, 62, 211-216. [CrossRef]

78. Cariou, P. Is slow steaming a sustainable means of reducing $\mathrm{CO}_{2}$ emissions from container shipping? Transp. Res. Part D Transp. Environ. 2011, 16, 260-264. [CrossRef]

79. Finnsgard, C.; Kalantari, J.; Roso, V.; Woxenius, J. The Shipper's perspective on slow steaming-Study of six Swedish companies. Trans. Policy 2020, 86, 44-49. [CrossRef]

80. Roberti, R.; Pacino, D. A Decomposition Method for Finding Optimal Container Stowage Plans. Transp. Sci. 2018, 52, 1444-1462. [CrossRef]

81. Brouer, B.D.; Dirksen, J.; Pisinger, D.; Plum, C.E.; Vaaben, B. The Vessel Schedule Recovery Problem (VSRP)—A MIP model for handling disruptions in liner shipping. Eur. J. Oper. Res. 2013, 224, 362-374. [CrossRef]

82. Li, C.; Qi, X.; Lee, C.-Y. Disruption Recovery for a Vessel in Liner Shipping. Transp. Sci. 2015, 49, 900-921. [CrossRef]

83. Li, C.; Qi, X.; Song, D. Real-time schedule recovery in liner shipping service with regular uncertainties and disruption events. Transp. Res. Part B Methodol. 2016, 93, 762-788. [CrossRef]

84. Cheraghchi, F.; Abualhaol, I.; Falcon, R.; Abielmona, R.; Raahemi, B.; Petriu, E. Modeling the speed-based vessel schedule recovery problem using evolutionary multiobjective optimization. Inf. Sci. 2018, 448-449, 53-74. [CrossRef]

85. Yao, Z.; Ng, S.H.; Lee, L.H. A study on bunker fuel management for the shipping liner services. Comput. Oper. Res. 2012, 39, 1160-1172. [CrossRef]

86. De, A.; Choudhary, A.; Turkay, M.; Tiwari, M.K. Bunkering policies for a fuel bunker management problem for liner shipping networks. Eur. J. Oper. Res. 2021, 289, 927-939. [CrossRef]

87. Waters, W. Impact of Yantian Disruption 'Exceeds the Suez Incident'. Lloyds Loading List, 11 June 2021. Available online: https:/ / www.lloydsloadinglist.com/freight-directory/news/Impact-of-Yantian-disruption-\%E2\%80\%98exceeds-the-Suezincident\%E2\%80\%99/79276.htm\#.YMwqjfKSnIU (accessed on 17 June 2021).

88. Steenken, D.; Voß, S.; Stahlbock, R. Container terminal operation and operations research-A classification and literature review. Contain. Termin. Autom. Trans. Syst. 2005, 26, 3-49. [CrossRef]

89. Stahlbock, R.; Voß, S. Operations research at container terminals: A literature update. OR Spectr. 2008, 30, 1-52. [CrossRef]

90. Carlo, H.J.; Vis, I.F.A.; Roodbergen, K.J. Seaside operations in container terminals: Literature overview, trends, and research directions. Flex. Serv. Manuf. J. 2015, 27, 224-262. [CrossRef]

91. Kim, K.H.; Lee, H. Container Terminal Operation: Current Trends and Future Challenges, In Handbook of Ocean Container Transport Logistics-Making Global Supply Chain Effective; Lee, C.-Y., Meng, Q., Eds.; Springer: New York, NY, USA, $2015 ;$ pp. 43-74.

92. Bierwirth, C.; Meisel, F. A survey of berth allocation and quay crane scheduling problems in container terminals. Eur. J. Oper. Res. 2010, 202, 615-627. [CrossRef]

93. Bierwirth, C.; Meisel, F. A follow-up survey of berth allocation and quay crane scheduling problems in container terminals. Eur. J. Oper. Res. 2015, 244, 675-689. [CrossRef]

94. Yang, C.; Wang, X.; Li, Z. An optimisation approach for coupling problem of berth allocation and quay crane assignment in container terminal. Comput. Ind. Eng. 2012, 63, 243-253. [CrossRef]

95. Ursavas, E. A decision support system for quayside operations in a container terminal. Decis. Support Syst. 2014, 59, 312-324 [CrossRef]

96. Zhen, L.; Jiang, X.; Lee, L.H.; Chew, E.P. A Review on Yard Management in Container Terminals. Ind. Eng. Manag. Syst. 2013, 12, 289-304. [CrossRef]

97. Covic, F. A literature review on container handling in yard blocks. In Computational Logistics. ICCL 2018. Lecture Notes in Computer Science; Cerulli, R., Raiconi, A., Voß, S., Eds.; Springer: Cham, Switzerland, 2018; Volume 11184.

98. Luo, J.; Wu, Y.; Mendes, A.B. Modelling of integrated vehicle scheduling and container storage problems in unloading process at an automated container terminal. Comput. Ind. Eng. 2016, 94, 32-44. [CrossRef]

99. Feng, Y.; Song, D.-P.; Li, D.; Zeng, Q. The stochastic container relocation problem with flexible service policies. Transp. Res. Part B Methodol. 2020, 141, 116-163. [CrossRef] 
100. Chen, G.; Govindan, K.; Yang, Z. Managing truck arrivals with time windows to alleviate gate congestion at container terminals. Int. J. Prod. Econ. 2013, 141, 179-188. [CrossRef]

101. Ambrosino, D.; Siri, S. Comparison of solution approaches for the train load planning problem in seaport terminals. Transp. Res. Part E 2015, 79, 65-82. [CrossRef]

102. Xie, Y.; Song, D.-P. Optimal planning for container prestaging, discharging, and loading processes at seaport rail terminals with uncertainty. Transp. Res. Part E Logist. Transp. Rev. 2018, 119, 88-109. [CrossRef]

103. Song, D.-W. Port co-opetition in concept and practice. Marit. Policy Manag. 2003, 30, 29-44. [CrossRef]

104. Asadabadi, A.; Miller-Hooks, E. Co-opetition in enhancing global port network resiliency: A multi-leader, common-follower game theoretic approach. Transp. Res. Part B Methodol. 2018, 108, 281-298. [CrossRef]

105. Lagoudis, I.N.; Theotokas, I.; Broumas, D. A literature review of port competition research. Int. J. Shipp. Transp. Logist. 2017, 9, 724. [CrossRef]

106. Wan, Y.; Zhang, A.; Li, K.X. Port competition with accessibility and congestion: A theoretical framework and literature review on empirical studies. Marit. Policy Manag. 2017, 45, 239-259. [CrossRef]

107. Mclaughlin, H.; Fearon, C. Understanding the development of port and regional relationships: A new cooperation/competition matrix. Marit. Policy Manag. 2013, 40, 278-294. [CrossRef]

108. Notteboom, T.; Rodrigue, J.P. Port regionalization: Towards a new phase in port development. Marit. Policy Manag. 2005, 32, 297-313. [CrossRef]

109. Mwemezi, J.J.; Huang, Y. Inland container depot integration into logistics networks based on network flow model: The Tanzanian perspective. Afr. J. Bus. Manag. 2012, 6, 7149-7157.

110. Lam, J.S.L.; Gu, Y. Port hinterland intermodal container flow optimisation with green concerns: A literature review and research agenda. Int. J. Shipp. Transp. Logist. 2013, 5, 257. [CrossRef]

111. Bouchery, Y.; Fazi, S.; Fransoo, J.C. Hinterland Transportation in Container Supply Chains. In Handbook of Ocean Container Transportation Logistics; Lee, C.Y., Meng, Q., Eds.; Springer: New York, NY, USA, 2015; pp. 497-520.

112. Wang, W.F.; Yun, W.Y. Scheduling for inland container truck and train transportation. Int. J. Prod. Econ. 2013, 143, 349-356. [CrossRef]

113. Fazi, S.; Roodbergen, K.J. Effects of demurrage and detention regimes on dry-port-based inland container transport. Transp. Res. Part C Emerg. Technol. 2018, 89, 1-18. [CrossRef]

114. Tao, X.; Wu, Q. Energy consumption and CO2 emissions in hinterland container transport. J. Clean. Prod. 2021, $279,123394$. [CrossRef]

115. Notteboom, T.E. The Time Factor in Liner Shipping Services. Marit. Econ. Logist. 2006, 8, 19-39. [CrossRef]

116. Bush, D. Logistics Industry Calls for UK Government Help on Port Congestion. Lloyds List, 9 December 2020. Available online: https: / /lloydslist.maritimeintelligence.informa.com/LL1135070 (accessed on 17 June 2021).

117. Porter, J. LA/Long Beach Anchorages Full as Cargo Surge Clogs Californian Supply Chains. Lloyds List, 29 December 2020. Available online: https:/ / lloydslist.maritimeintelligence.informa.com/LL1135250 (accessed on 17 June 2021).

118. Tirschwell, P. Fewer 'No Shows' Key to Service Contract Evolution. The Journal of Commerce Online, 8 May 2017. Available online: https:/ / www.joc.com/maritime-news/container-lines/predictability-cargo-flows-vital-cost-savings_20170508.html (accessed on 17 June 2021).

119. Johnson, E. Maersk Revives No-Show Fees for Bookings. The Journal of Commerce Online, 25 June 2019. Available online: https://www.joc.com/maritime-news/container-lines/maersk-line/maersk-revives-no-show-fees-bookings_20190625.html (accessed on 17 June 2021).

120. Feibert, D.C.; Hansen, M.S.; Jacobsen, P. An Integrated Process and Digitalization Perspective on the Shipping Supply, Chain-A Literature Review. In Proceedings of the 2017 IEEE International Conference on Industrial Engineering and Engineering Management, Singapore, 10-13 December 2017.

121. Egloff, C.; Sanders, U.; Georgaki, K.; Riedl, J. The Digital Imperative in Container Shipping. BCG Shipping Portal, 2 February 2018. Available online: https://www.bcg.com/publications/2018/digital-imperative-container-shipping (accessed on 17 June 2021).

122. Lambrou, M.; Watanabe, D.; Iida, J. Shipping digitalization management: Conceptualization, typology and antecedents. J. Shipp. Trade 2019, 4, 1-17. [CrossRef]

123. Yang, C.-S. Maritime shipping digitalization: Blockchain-based technology applications, future improvements, and intention to use. Transp. Res. Part E Logist. Transp. Rev. 2019, 131, 108-117. [CrossRef]

124. Anwar, M.; Henesey, L.; Casalicchio, E. Digitalization in container terminal logistics: A literature review. In Proceedings of the 27th Annual Conference of International Association of Maritime Economists, Athens, Greece, 25-28 June 2019 ; pp. 1-25.

125. Rossiter, C.M.; Pearch, B.W. Communicating Personally; Macmillan: New York, NY, USA, 1975.

126. Baker, J. Maersk's Integration Strategy begins to Pay off. Lloyds List, 5 May 2021. Available online: https://1loydslist. maritimeintelligence.informa.com/LL1136678 (accessed on 17 June 2021).

127. Olmer, N.; Comer, B.; Roy, B.; Mao, X.; Rutherford, D. Greenhouse Gas Emissions from Global Shipping, 2013-2015; International Council on Clean Transportation: Washington, DC, USA, 2017.

128. Bouman, E.A.; Lindstad, E.; Rialland, A.I.; Strømman, A.H. State-of-the-art technologies, measures, and potential for reducing GHG emissions from shipping-A review. Transp. Res. Part D Transp. Environ. 2017, 52, 408-421. [CrossRef] 
129. Shi, W.; Xiao, Y.; Chen, Z.; McLaughlin, H.; Li, K.X. Evolution of green shipping research: Themes and methods. Marit. Policy Manag. 2018, 45, 863-876. [CrossRef]

130. Lagouvardou, S.; Psaraftis, H.N.; Zis, T. A Literature Survey on Market-Based Measures for the Decarbonization of Shipping. Sustainability 2020, 12, 3953. [CrossRef]

131. Rutherford, D.; Comer, B. The International Maritime Organization's Initial Greenhouse Gas Strategy; International Council on Clean Transportation: Washington, DC, USA, 2018.

132. DNV. Maritime Forecast to 2050-Energy Transition Outlook 2020; DNV GL: Hovik, Norway, 2020.

133. Englert, D.; Losos, A.; Raucci, C.; Smith, T. The Role of LNG in the Transition toward Low-and Zero-Carbon Shipping; World Bank: Washington, DC, USA, 2021.

134. Tan, H.H. Shipowners Rank LNG as Top Fuel in Energy Transition. Lloyds List, 5 May 2021. Available online: https:/ /lloydslist. maritimeintelligence.informa.com/LL1136674 (accessed on 17 June 2021).

135. Adamopoulos, A. Shipping Leaders Disagree on Future of LNG in Shipping. Lloyds List, 12 May 2021. Available online: https:/ / lloydslist.maritimeintelligence.informa.com/LL1136761 (accessed on 17 June 2021).

136. GEF-UNDP-IMO. Port Emissions Toolkit, Guide No.1, Assessment of Port Emissions. Global Maritime Energy Efficiency Partnerships (GloMEEP) and International Association of Ports and Harbors (IAPH); Elephant Print: Lewes, UK, 2018.

137. GEF-UNDP-IMO. Port Emissions Toolkit, Guide No.2, Development of Port Emissions Reduction Strategies. Global Maritime Energy Efficiency Partnerships (GloMEEP) and International Association of Ports and Harbors (IAPH); Elephant Print: Lewes, UK, 2018.

138. Iris, Ç.; Lam, J.S.L. A review of energy efficiency in ports: Operational strategies, technologies and energy management systems. Renew. Sustain. Energy Rev. 2019, 112, 170-182. [CrossRef] 